\title{
Investigation of the Effect of Six Weeks Electro Muscle Stimulation Training on Physical Changes in the Sedentary Men and Women ${ }^{*}$
}

\author{
Tahir Kıllı̧ ${ }^{1}$, Alkan Ugurlu ${ }^{1}$, Sinan Kal ${ }^{1}$ \\ ${ }^{1}$ Akdeniz University, Turkey \\ Correspondence: Tahir Kılıç, Akdeniz University, Turkey.
}

Received: June 11, 2018

Accepted: July 2, $2018 \quad$ Online Published: July 3, 2018

doi:10.11114/jets.v6i9.3347

URL: https://doi.org/10.11114/jets.v6i9.3347

\begin{abstract}
The purpose of this study was to investigation of the effect of six weeks electro stimulation training on physical changes in the sedentary men and women. Electro muscle stimulation (EMS), which is applied since the discovery of contraction under the influence of electrical currents, on the purpose of rehabilitation and treatment purposes, has attracted the attention of coaches, athletes and sports scientists as a popular training method over time. In the present research, 6 weeks, 3 days a week and for 25 minutes in a day of EMS machine training program was applied to the sedentary women $_{\mathrm{n}=12}$ and sedentary men $\mathrm{n}_{\mathrm{n} 12}$. In order to determine effect of EMS machine training on the physical changes which are body mass, \% body fat, fat mass, body mass index, total body water, fat free mass, muscle mass, Tanita (SC-300) Body Composition Analyzer was used as a pre-test and post-test. The results of the Tanita body measurements were analyzed by using SPSS computer program, the standard deviations were calculated, and pre- and post-training statistical paired samples T Test analysis were made. According to SPSS analysis results, there are statistically significant increases in the \% body fat, fat mass, soft muscle tissues, extracellular and intracellular liquid weights and cell mass weights $(\mathrm{p}<0.05)$. There are increases in other results which is, body mass, BMI, muscle mass, metabolic ages, obesity levels, internal fat, bone mineral weights and skeletal muscle mass, but not statistically significant $(p>0.05)$. Only EMS training has increased the maximum power associated with sports, due to the increase in the speed of movement. In addition, the stronger long-term effects of EMS training provide new opportunities, as determined by the duration of the training. The right application of full-body EMS training with dynamic exercise movements is a promising combination for power and speed training.
\end{abstract}

Keywords: Electro Muscle Stimulation (EMS), bioelectrical impedance analysis, physical changes, sedentary, training, body composition

\section{Introduction}

EMS means electrical muscle stimulation. During classical exercises, the brain sends electrical signals that allow the muscles to contract and move. Thanks to EMS, much more intense stimuli are sent to the muscles from the outside in addition to the signals sent by the brain. Stimulations cause muscle contractions. Besides the agonist and antagonist muscles, balancing muscles, which are difficult to be reached at the same time, are activated, so full body work is achieved. Muscles can be worked much more intensively and for longer periods of time than conventional methods, without using any weight and without any force on the joints (Delitto et al. 1989). EMS can be defined as electrical currents are applied to the muscle tissue or motor points (Kale et al. 2014). All major muscle groups work together to avoid unilateral strain. The imbalance between muscles is targeted and dramatically reduced. When certain movements are performed during stimulation and certain muscle chains are triggered consciously, the coordinated phenomenon is provided (Eriksson et al. 1981).

Relevant research in particular has reported that there are the positive results of EMS training with sedentary. Laughman et. al., (1983) have found that the electrical-stimulation and isometric-exercise groups had statistically significant increases in quadriceps femoris muscle torque when compared with the non-exercised controls. The data supported the use of this electronic stimulator as an appropriate device for strengthening skeletal muscle without

*It is presented as a poster presentation at the 1st International Sports Sciences Tourism and Recreation Student Congress.Turkey/Antalya (21-23.05.2014) 
voluntary effort. Amiridis et. al., 2005 stated that ES training resulted in decreased postural sway, greater ankle muscles EMG activity, greater stability of the ankle joint and significant changes in mean position of all three joints of the lower limb. In addition, dorsiflexion moment significantly increased as a result of ES training. Banerjee et. al., 2005 find in the research that a group of sedentary adult subjects demonstrated significant improvements in exercise capacity (including cardiovascular fitness and muscle strength) as a result of a period of EMS-EX training.

On the other hand some researchers have found that EMS training has no positive effect or improvement (Maffiuletti et al. 2000; Venable et. al., 1991; Porcari et. al., 2002; Holcomb, 2006; Paillard et. al., 2008; Gulick et. al., 2011). The main purpose of this study is to demonstrate the physical changes differences of the sedentary men and women resulting from the 6-week training program with the EMS device. For six (6) weeks, three days a week for 25 minutes EMS machine training program was applied to the sedentary women ${ }_{\mathrm{n}=12}$ and men $_{\mathrm{n}=12}$.

\section{Method}

The main purpose of this study is to demonstrate the physical changes of the sedentary men and women resulting from the 6-week training program with the EMS device.

A total of 24 subjects who are men=12 with a mean age of $30.75 \pm 10.1$, a mean height $(\mathrm{cm})$ of $177.66 \pm 8.1$, a mean weight $(\mathrm{Kg}$.) of $79.22 \pm 10.77$ and women $\mathrm{n}=12$ with a mean age of $36.50 \pm 9.94$, a mean height $(\mathrm{cm})$ of $165.75 \pm 4.91$ women a mean weight (Kg.) of $66.33 \pm 10.11$, participated in the study.

Three days a week for 25 minutes EMS machine training program was applied to the participant women $\mathrm{n}=12$ with an average age of $36.50 \pm 9.94$ and men $n=12$ with an average age of $30.75 \pm 10.11$.

Subjects' first measurements were taken with Tanita (SC-300) before the 6-week training program. Second measurements were taken, and body analyzes were performed after 6 weeks training program with EMS device, Tanita the body measurement scale device has been used in order to be able to demonstrate the physical changes.

The results of the Tanita body measurements were analyzed by using SPSS Statistics Base (version 23), the standard deviations were calculated, and pre- and post-training statistical paired samples $\mathrm{T}$ Test analysis were made. The results are shown with tables and graphics.

\section{Results}

According to SPSS analysis results, there are statistically significant increases in the \% body fat, fat mass, soft muscle tissues, extracellular and intracellular liquid weights and cell mass weights $(\mathrm{p}<0.05)$. There is increases in other results which is, body mass, BMIs, muscle weights, metabolic ages, obesity levels, internal fat, bone mineral weights and skeletal muscle weights, but not statistically significant ( $p>0.05)$.

Table I. Pre-Test ve Post-Test Body Composition Analysis

\begin{tabular}{llllll}
\hline & \multicolumn{3}{c}{ Women $_{\mathrm{n}=12}$} & $\mathrm{Men}_{\mathrm{n}=12}$ & $\mathrm{P}$ \\
\cline { 2 - 5 } & Pre - test (sd) & Post - test (sd) & Pre - test (sd) & Post - test $(\mathrm{sd})$ & \\
\hline Body mass (weight) & $66.33( \pm 10.11)$ & $60.31( \pm 20.34)$ & $79.22( \pm 10.77)$ & $78.25( \pm 9.59)$ & 0.223 \\
BMI & $24.14( \pm 3.53)$ & $23.78( \pm 3.04)$ & $25.07( \pm 2.39)$ & $24.73( \pm 1.60)$ & 0.113 \\
\% Body fat & $31.41( \pm 5.99)$ & $29.65( \pm 5.50)$ & $16.28( \pm 7.11)$ & $13.56( \pm 5.46)$ & 0.000 \\
Fat mass (fat weights) & $21.34( \pm 7.22)$ & $19.75( \pm 6.26)$ & $13.23( \pm 6.47)$ & $10.76( \pm 4.73)$ & 0.000 \\
Total body liquid & $32.94( \pm 2.61)$ & $33.35( \pm 2.25)$ & $48.61( \pm 5.73)$ & $49.40( \pm 5.82)$ & 0.088 \\
Fat-free body mass & $45.00( \pm 3.55)$ & $45.60( \pm 3.15)$ & $66.17( \pm 7.79)$ & $66.94( \pm 7.85)$ & 0.118 \\
Muscle mass & $42.75( \pm 3.35)$ & $43.30( \pm 2.92)$ & $62.98( \pm 7.47)$ & $59.87( \pm 19.34)$ & 0.578 \\
\hline
\end{tabular}


Table II. Body Mass Analysis

\begin{tabular}{|c|c|c|c|c|}
\hline & Section & Gender & Std. Dev. & $\mathrm{P}$ \\
\hline \multirow{2}{*}{ Pre-Test } & \multirow{2}{*}{ Soft Muscle Tissues (Kg) } & $\operatorname{Men}_{n=12}$ & $61.29 \pm 7.25$ & \multirow{4}{*}{$0.048^{*}$} \\
\hline & & Women $_{\mathrm{n}=12}$ & $41.79 \pm 3.27$ & \\
\hline \multirow{2}{*}{ Post-Test } & \multirow{2}{*}{ Soft Muscle Tissues (Kg) } & Men $_{n=12}$ & $62.54 \pm 7.13$ & \\
\hline & & Women $_{\mathrm{n}=12}$ & $42.32 \pm 2.82$ & \\
\hline \multirow{2}{*}{ Pre-Test } & \multirow{2}{*}{ Bone Mineral Weights $(\mathrm{Kg})$} & Men $_{n=12}$ & $3.08 \pm 0.54$ & \multirow{4}{*}{0.241} \\
\hline & & Women $n=12$ & $2.24 \pm 0.21$ & \\
\hline \multirow{2}{*}{ Post-Test } & \multirow{2}{*}{ Bone Mineral Weights $(\mathrm{Kg})$} & Men $_{n=12}$ & $3.14 \pm 0.53$ & \\
\hline & & Women $_{\mathrm{n}=12}$ & $2.25 \pm 0.15$ & \\
\hline \multirow{2}{*}{ Pre-Test } & \multirow{2}{*}{ Skeletal Muscle (Kg) } & $\operatorname{Men}_{n=12}$ & $34.30 \pm 10.47$ & \multirow{4}{*}{0.215} \\
\hline & & Women $_{\mathrm{n}=12}$ & $25.47 \pm 2.01$ & \\
\hline \multirow{2}{*}{ Post-Test } & \multirow{2}{*}{ Skeletal Muscle (Kg) } & Men $_{n=12}$ & $38.20 \pm 4.49$ & \\
\hline & & Women $_{\mathrm{n}=12}$ & $25.79 \pm 1.73$ & \\
\hline \multirow{2}{*}{ Pre-Test } & \multirow{2}{*}{ Extracellular Liquid (Kg) } & Men $_{n=12}$ & $20.46 \pm 2.45$ & \multirow{4}{*}{$0.035^{*}$} \\
\hline & & Women $_{n=12}$ & $13.93 \pm 1.10$ & \\
\hline \multirow{2}{*}{ Post-Test } & \multirow{2}{*}{ Extracellular Liquid (Kg) } & $\operatorname{Men}_{\mathrm{n}=12}$ & $20.89 \pm 2.46$ & \\
\hline & & Women $_{n=12}$ & $14.11 \pm 0.95$ & \\
\hline \multirow{2}{*}{ Pre-Test } & \multirow{2}{*}{ Intracellular Liquid (Kg) } & Men $_{n=12}$ & $27.90 \pm 3.33$ & \multirow{4}{*}{$0.031 *$} \\
\hline & & Women $_{\mathrm{n}=12}$ & $19.00 \pm 1.50$ & \\
\hline \multirow{2}{*}{ Post-Test } & \multirow{2}{*}{ Intracellular Liquid (Kg) } & Men $_{n=12}$ & $28.51 \pm 3.35$ & \\
\hline & & Women $_{\mathrm{n}=12}$ & $19.24 \pm 1.29$ & \\
\hline \multirow{2}{*}{ Pre-Test } & \multirow{2}{*}{ Cell Mass (Kg) } & Men $_{n=12}$ & $42.52 \pm 5.02$ & \multirow{4}{*}{$0.025^{*}$} \\
\hline & & Women $_{n=12}$ & $28.82 \pm 2.24$ & \\
\hline \multirow{2}{*}{ Post-Test } & \multirow{2}{*}{ Cell Mass (Kg) } & $\operatorname{Men}_{n=12}$ & $43.46 \pm 5.02$ & \\
\hline & & Women $_{\mathrm{n}=12}$ & $29.19 \pm 1.96$ & \\
\hline
\end{tabular}

$* \mathrm{p}<0,05$

A total of 24 subjects who are men $_{n=12}$ with a mean age of $30.75 \pm 10.11$ and women a mean age of $36.50 \pm 9.94 \mathrm{n}=12$ were included in the study. When the body mass variable of subjects is analyzed pre-test is found as $79.22 \mathrm{~kg} \pm 10.77$ and post-test is found as $78.25 \mathrm{~kg} \pm 9.59$ for men; pre-test is found as $66.33 \mathrm{~kg} \pm 10.11$ and post-test is found as $60.31 \mathrm{~kg} \pm 20.34$ for women. The statistical significant level is $\mathrm{p}=0.223(\mathrm{p}>0.05)$. When the BMI variable of subjects is analyzed pre-test is found as $25.07 \mathrm{~kg} / \mathrm{m} 2 \pm 2.39$ and post-test is found as $24.73 \mathrm{~kg} / \mathrm{m} 2 \pm 1.60$ for men; pre-test is found as 24.14 $\mathrm{kg} / \mathrm{m} 2 \pm 3.53$ and post-test is found as $23.78 \mathrm{~kg} / \mathrm{m} 2 \pm 3.04$ for women. The statistical significant level is $\mathrm{p}=0.113$ ( $\mathrm{p}>0.05$ ). When the body fat rate variable of subjects is analyzed pre-test is found as \%16.28 \pm 7.11 and post-test is found as $\% 13.56 \pm 5.46$ for men; pre-test is found as $\% 31.41 \pm 5.99$ and post-test is found as $\% 29.65 \pm 5.50$ for women. The statistical significant level is $\mathrm{p}=0.000(\mathrm{p}<0.05)$. When the fat mass variable of subjects is analyzed pre-test is found as $\% 13.23 \pm 6.47$ and post-test is found as $\% 10.76 \pm 4.73$ for men; pre-test is found as $\% 21.34 \pm 7.22$ and post-test is found as $\% 19.75 \pm 6.26$ for women. The statistical significant level is $\mathrm{p}=0.000(\mathrm{p}<0.05)$. When the total body liquid variable of subjects is analyzed pre-test is found as $48.61 \pm 5.73$ and post-test is found as $49.40 \pm 5.82$ for men; pre-test is found as $32.94 \pm 2.61$ and post-test is found as $33.35 \pm 2.25$ for women. The statistical significant level is $\mathrm{p}=0.088(\mathrm{p}>0.05)$. When the fat-free body mass variable of subjects is analyzed pre-test is found as $66.17 \mathrm{~kg} \pm 7.79$ and post-test is found as $66.94 \mathrm{~kg} \pm 7.85$ for men; pre-test is found as $45.00 \mathrm{~kg} \pm 3.55$ and post-test is found as $45.60 \mathrm{~kg} \pm 3.15$ for women. The statistical significant level is $\mathrm{p}=0.118$ ( $\mathrm{p}>0.05)$. When the muscle mass variable of subjects is analyzed pre-test is found as $62.98 \mathrm{~kg} \pm 7.47$ and post-test is found as $59.87 \mathrm{~kg} \pm 19.34$ for men; pre-test is found as $42.75 \mathrm{~kg} \pm 3.35$ and post-test is found as $43.30 \mathrm{~kg} \pm 2.92$ for women. The statistical significant level is $\mathrm{p}=0.578(\mathrm{p}>0.05)$.

\section{Discussion}

When the literature is reviewed, Banerjee et al. (2005) concluded that electrical muscle stimulation training and exercise programs in sedentary for 6 weeks (29 sessions of quadriceps, hamstring, gluteal and calf muscles) have developed physical fitness and can be regarded that the sedentary is a proper training form for adult population (Wolf et al., 1986). Colson et. al. (2009) have found significant strength enhancement by isometric, eccentric, and concentric muscle contraction strength compared to the control group, with arm muscle force training exercises performed three times a week for a total of seven weeks with EMS device. The study by Maffiuletti (2010) stated that in the force trainings with EMS devices, the motor units participating in the training will increase and this increase will have positive effects on muscle length and strength.

Lake (1992), in his research reported that EMS devices used for therapeutic purposes would provide muscle development without muscle hypertrophy and EMS exercises applied to the selected muscles had positive effects on the working of edema muscles.

Porcari et. al. (2002) conducted a three-day-a-week EMS training on a group of 16 subjects in their study and reported that there was no significant change when compared with the control group of 11 persons. 
Babault et. al. (2007) performed a study with rugby players, and conducted leg upper group muscle strength trainings three times a week for six weeks and it has been reported that EMS training has very positive effects on leaping strength and leg upper group muscles. It has also been reported that EMS training does not produce a significant improvement in speed and rugby skill tests in the same study. The current study reveals, when compared to various training methods, dynamic full-body EMS training with EMS offers a highly effective training method for increasing strength, reducing edema and reducing body fat percentage.

Only EMS training has increased the maximum power associated with sports, due to the increase in the speed of movement. In addition, the stronger long-term effects of EMS training provide new opportunities, as determined by the duration of the training. The right application of full-body EMS training with dynamic exercise movements is a promising combination for power and speed training.

\section{References}

Amiridis, I., Arabatzi, F., Violaris, P., Stavropoulos, E., \& Hatzitaki, V. (2005). Static balance improvement in elderly after dorsiflexors electrostimulation training. European Journal of Applied Physiology, 94(4), 424-433. https://doi.org/10.1007/s00421-005-1326-3

Babault, N., Cometti, G., Bernardin, M., Pousson, M., \& Chatard, J. C. (2007). Effects of ems training on muscle strength and power of elite rugby players. Journal Of Strength And Conditions Research, 21(2), 431-437.

Banerjee, P., Caulfield, B., Crowe, L., \& Clark, A. (2005). Prolonged electrical muscle stimulation exercise improves strength and aerobic capacity in healthy sedentary adults. Journal of Applied Physiology, 99(6), 2307-2311. https://doi.org/10.1152/japplphysiol.00891.2004

Bobbert, M. F., \& Van Soest, A. J. (1994). Effects of muscle strengthening on vertical jump height: a simulation study. Med. Sci. Sports Exerc., 26, 1012-1020. https://doi.org/10.1249/00005768-199408000-00013

Colson, S. S., Martin, A., \& Van Hoecke, J. (2009). Effects of electromyostimulation versus voluntary isometric training on elbow flexor muscle strength. Journal of Electromyography and Kinesiology, 19, E311-E319. https://doi.org/10.1016/j.jelekin.2008.05.009

Delitto, A., Brown, M., Strube, M. J., Rose, S. J., \& Lehman, R. C. (1989). Electrical stimulation of quadriceps femoris in an elite weight lifter: a single subject experiment. Int. J. Sports Med., 10, 187-191. https://doi.org/10.1055/s-2007-1024898

Eriksson, E., Haggmark, T., Kiessling, H., \& Karlsson, J. (1981). Effect of electrical stimulation on human Skeletal Muscle. Int. J. Sports Med., 2, 18-22. https://doi.org/10.1055/s-2008-1034578

Gulick, D. T., Castel, J. C., Francis, X. P., \& Draper, D. O. (2011). Effect of patterned electrical neuromuscular stimulation on vertical jump in collegiate athletes. Sports Health: A Multidisciplinary Approach, 3(2), 152-157. https://doi.org/10.1177/1941738110397871

Holcomb, W. R. (2006). Effect of training with neuromuscular electrical stimulation on elbow flexion strength. Journal of Sports Science and Medicine, 5, 276-281.

Kale, M., Kaçoğlu, C., \& Gürol, B. (2014). Elektromyostimülasyon antrenmanlarının nöral adaptasyon ve sportif performans üzerine etkileri. Spor Bilimleri Dergisi Hacettepe Journal of Sport Sciences, 25(3), 142-158.

Lake, D. A. (1992). Neuromuscular electrical stimulation. Sports Medicine, 13(5), 320-336. https://doi.org/10.2165/00007256-199213050-00003

Laughman, R. K., Youdas, J. W., Garrett, T. R., \& Chao, E. Y. S. (1983). Strength changes in the normal quadriceps femoris muscle as a result of electrical stimulation, Physical Therapy, 63(4), 494-499. https://doi.org/10.1093/ptj/63.4.494

Maffiuletti, N. A. (2010). Physiological and methodological considerations for the use of neuromuscular electrical stimulation. European Journal of Applied Physiology, 110, 223-234. https://doi.org/10.1007/s00421-010-1502-y

Maffiuletti, N. A., Comettii, G., Amiridis, I. G., Martin, A., Pousson, M., \& Chatard, J. C. (2000). The effects of electromyostimulation training and basketball practice on muscle strength and jumping ability. Int. J. Sports Med., 21, 437-443. https://doi.org/10.1055/s-2000-3837

Paillard, T., Noe, F., Bernard, N., Dupui, P., \& Hazard, C. (2008). Effects of two types of neuromuscular electrical stimulation training on vertical jump performance. Journal of Strength and Conditioning Research, 22, 1273-1278. https://doi.org/10.1519/JSC.0b013e3181739e9c

Porcari, J. P., Mclean, K. P., Foster, C., Kernozek, T., Crenshaw, B., \& Swenson, C. (2002). Effects of electrical muscle 
stimulation on body composition, muscle strength, and physical appearance. Journal of Strength and Conditioning Research, 16(2), 165-172.

Venable, M. P., Collins, M. A., O'Bryant, H. S., Denegar, C. R., Sedivec, M. J., \& Alons, G. (1991). Effect of Supplemental Electrical Stimulation on the Development of Strength, Vertical Jump Performance and Power. The Journal of Strength \& Conditioning Research, 5(3), 139-143.

Wolf, S. L., Ariel, G. B., Saar, D., Penny, M. A., \& Railey, P. (1986). The Effect of Muscle Stimulation During Resistive Training on Performance Parameters. Am. J. Sports Med., 14, 18-23. https://doi.org/10.1177/036354658601400104

\section{Copyrights}

Copyright for this article is retained by the author(s), with first publication rights granted to the journal.

This is an open-access article distributed under the terms and conditions of the Creative Commons Attribution license which permits unrestricted use, distribution, and reproduction in any medium, provided the original work is properly cited. 